Justyna Eska-Mikołajewska

Bydgoska Szkoła Wyższa

justynaeska.25@gmail.com

ORCID ID: https://orcid.org/0000-0001-7681-2425

\title{
Konsekwencje ustrojowe reform systemu wyborczego Fidżi jako państwa funkcjonującego w warunkach społeczeństwa podzielonego etnicznie
}

\author{
Constitutional Consequences of Reforms on the Fijian Electoral System \\ as a State Functioning in the Conditions of an Ethnically Divided Society
}

\begin{abstract}
The article presents the issues of the Fijian electoral system. As Fiji in the initial period of its existence was a British colony, its legal and political system was influenced by the Westminster form of government. The political system and the policy of independent Fiji have since been shaped by an ethnic factor, and more specifically the relationship between the indigenous population and the Indo-Fijians who have arrived in Fiji since the nineteenth century. The gradual escalation of tension in the state led to as many as four coups, practically alternated with democratic elections, the rules of which have been regulated by four successive constitutions. The analysis undertaken allows to present the evolution of the electoral system against the background of the development of Fijian constitutionalism from the moment of independence until adoption of the Constitution of the Republic of Fiji in 2013. The evaluation of how electoral reforms influenced political cooperation in this state, also allows to indicate that the solution of problems related to its functioning will not occur through frequent institutional changes as they do not create a stable legal framework. Conversely, they contribute to the escalation of the conflict in the struggle for a power that is representative and able to rule. In this article, the author has adopted the following research methods: the critical analysis method and descriptive method as well as the analysis of legal sources.
\end{abstract}

Keywords: electoral system, constitution, Fiji, ethnicity, ethnically divided society

Słowa kluczowe: system wyborczy, konstytucja, Fidżi, tożsamość etniczna, społeczeństwo podzielone etnicznie 


\section{Wprowadzenie}

Fidżi to niewielkie państwo w zachodniej części Oceanii (Melanezji) ${ }^{1}$, które w II połowie XIX w. włączono w skład Imperium Brytyjskiego. Wewnętrzną autonomię uzyskało w 1966 r., a status dominium wraz z przyjęciem pierwszej konstytucji w dniu 10 października 1970 r. $^{2}$. Państwo to doświadczyło zarówno radykalnej zmiany ustrojowej, związanej z przyjęciem republikańskiej formy rządów w 1987 r., czterech przewrotów, jak i kryzysu konstytucyjnego w 2009 r., który doprowadził do ogłoszenia stanu wyjątkowego. Fidżi po raz pierwszy w historii zawieszono w prawach członka Wspólnoty Narodów (Commonwealth). Pogorszeniu uległa także sytuacja gospodarcza kraju, warunkowana ostrymi podziałami etnicznymi w społeczeństwie, które wzmacniane były przez ustanowiony system własności ziemi.

W trwającym niespełna 50 lat okresie państwowości fidżyjskiej weszły w życie aż cztery ustawy zasadnicze. Obecnie obowiązująca konstytucja, na mocy której przeprowadzono zasadnicze zmiany prawa wyborczego, została ogłoszona we wrześniu 2013 r. Wprowadzone regulacje prawne mają charakter przełomowy, gdyż świadczą o zanegowaniu dotychczasowego podejścia. Zgodnie z nim bazę dla istniejącego porządku instytucjonalnego stanowił wieloetniczny charakter społeczeństwa, a konkretnie relacje pomiędzy rodzimymi Fidżyjczykami (indigenous Fijian) ${ }^{3}$ a Hindusami (Indo-Fijians), przybywającymi na terytorium Fidżi od XIX w. Etniczność determinowała kształt ustroju i prowadzoną politykę, wpływając na sytuację gospodarczą i utrudniając pozytywną percepcję tego państwa przez otoczenie międzynarodowe ${ }^{4}$.

Celem artykułu jest ukazanie genezy i istoty najważniejszych reform wyborczych Fidżi wraz z ich konsekwencjami dla ustroju państwa. Ewolucja systemu wyborczego zaprezentowana zostanie na tle rozwoju konstytucjonalizmu fidżyjskiego od momentu uzyskania niepodległości do przyjęcia ustawy zasadniczej w $2013 \mathrm{r}$. Prześledzenie i ocena reform ordynacji wyborczej stanowi asumpt dla przyjętej hipo-

1 Całkowita powierzchnia tego państwa, obejmującego łącznie 332 wyspy, to $18274 \mathrm{~km}^{2}$ (157 miejsce na świecie). Liczba ludności Fidżi (stan na czerwiec 2018 r.) wynosi 926276 (161 miejsce na świecie) - CIA World Factbook, www.cia.gov/library/publications/the-world-factbook/geos/ fj.html (06.02.2019).

2 Była to najbardziej stabilna konstytucja Fidżi, zwana konstytucją niepodległości (independence constitution). Ustanawiała system polityczny podobny do funkcjonującego w innych koloniach brytyjskich. Bikameralny organ ustawodawczy tworzyły: 52-osobowa Izba Reprezentantów (House of Representatives), reprezentująca dwie główne społeczności Fidżi, oraz 22-osobowy Senat (Senate), ustanowiony w celu ochrony interesów rdzennej ludności; Y. Ghai, J. Cottrell, A tale of three constitutions: Ethnicity and politics in Fiji, „International Journal of Constitutional Law” 2007, nr 4, z. 5, s. 644-645.

3 Oryginalne określenie ludności rdzennie etnicznej Fidżi to iTaukei; zob. S. Chand, The Political Economy of Fiji: Past, Present and Prospects, „The Round Table” 2015, nr 2, z. 104, s. 199.

Członkostwo Fidżi w Commonwealth oficjalnie przywrócono po uznaniu wyniku wyborów z 17 września 2014 r.; Fiji: Constitution and Politics, www.thecommonwealth.org/our-member-countries/fiji/constitution-politics (06.02.2019). 
Konsekwencje ustrojowe reform systemu wyborczego Fidżi jako państwa...

tezy badawczej. Zakłada ona, że częste zmiany instytucjonalne (jak nowe konstytucje, modyfikacja prawa wyborczego), powodowane nierzadko doraźnymi kalkulacjami politycznymi, nie tworzą stabilnych ram prawnych, co - zwłaszcza w społeczeństwach o podzielonej strukturze etnicznej - przyczynia się do eskalacji konfliktu o wyłonienie reprezentatywnej i zdolnej do rządzenia władzy.

\section{Tradycja versus zwyczaj: westminsterskie dziedzictwo $\mathrm{w}$ praktyce ustrojowej Fidżi}

Na gruncie nauk prawnych system wyborczy stanowi ogół norm i zasad określających tryb przygotowania i przeprowadzenia wyborów. Odnosi się on do reguł, które pozwalają dokonać wyboru spośród potencjalnych opcji wyborczych, określić sposób ujawniania indywidualnych preferencji politycznych podczas procesu wyborczego, umożliwić wyborcom dostęp do informacji na temat kandydatów, jak i dokonanie aktu głosowania na wybranego kandydata (partię polityczną), dokonać transformacji głosów na mandaty, a także zachować społeczną kontrolę nad poprawnością, legalnością oraz uczciwością przebiegu wyborów ${ }^{5}$. System wyborczy $\mathrm{w}$ rozumieniu prawniczym jest utożsamiany z prawem wyborczym, ściśle zaś z całokształtem zasad prawnych zawartych zarówno w normach prawa wyborczego, tj. w konstytucjach czy ustawach wyborczych, jak i wynikających z praktyki wyborczej ${ }^{6}$.

Jako że punkt wyjścia do kształtowania się systemu ustrojowego Fidżi stanowiła westminsterska forma rządów ${ }^{7}$, także system wyborczy pozostawał pod wpływem wzorców brytyjskich. Był to system większościowy oparty na większości względnej (first-past-the -post, FTPT), funkcjonujący w zgodzie z regułą „zwycięzca bierze wszystko". Jego istotą jest to, że mandat zdobywa ten kandydat (czy ugrupowanie polityczne), który zgromadził określoną prawem większość głosów w danym okręgu wyborczym. Preferując partie duże, formuła większościowa korzystnie wpływa na budowanie przez nie stabilnej większości w parlamencie. Jednocześnie system ten generuje wysoki odsetek głosów bezskutkowych. Liczba otrzymywanych mandatów zwykle bowiem nie odpowiada faktycznej sile poparcia, co sprzyja deformacjom wyniku ${ }^{8}$.

5 B. Michalak, A. Sokala, Leksykon prawa wyborczego i systemów wyborczych, Warszawa 2010, s. 150.

6 A. Żukowski, Systemy wyborcze, Olsztyn 1999, s. 51.

7 W katalogu cech tego modelu szczególne znaczenie dla ustroju fidżyjskiego miała unitarna forma rządów, asymetryczny bikameralizm oraz większościowy system wyborczy; zob. A. Lijphart, Democracies. Patterns of Majoritarian and Consensus Government in Twenty-One Countries, New Haven and London 1984, s. 4-9.

8 Zob. J. Świeca, Współczesne systemy demokratyczne cz. I. Wybrane zagadnienia z problematyki wyborczej oraz makroanalizy systemowej w ujęciu porównawczym, Kielce 2003, s. 68. 
Jednym z efektów ubocznych ordynacji większościowej, który ujawnił się na Fidżi, było zjawisko utrwalania się dwupartyjności, prowadzące do ekstremalnej wręcz sztywności bipolarnego systemu politycznego. Dwubiegunowy układ sił tworzony od lat 60. XX w. obejmował ugrupowania polityczne zorganizowane wedle kryterium rasy, $z$ jednym dominującym stronnictwem w ramach każdej społeczności. Przedstawicielem rdzennych Fidżyjczyków stał się Sojusz (Alliance Party), który rozszerzając aktywność polityczną poza swój tradycyjny elektorat, odniósł sukces w kształtowaniu wieloetnicznego przywództwa przy wydatnym wsparciu Hindusów (24\% poparcia w 1972 r. $)^{9}$. Reprezentantem ludności hinduskiej była natomiast Partia Federacji Narodowej (National Federation Party, NFP).

W pierwszym etapie kształtowania się systemu wyborczego na Fidżi utrzymywała się wyraźna dominacja rdzennej ludności, zarówno w ramach władzy wykonawczej, strukturze administracji państwowej, jak i treści aktów prawnych. Zagwarantowanie nadrzędnego prawa do ziemi rdzennym mieszkańcom, zgodnie z postanowieniami aktu cesji (Deed of Cession), stanowiło fundament brytyjskiej polityki kolonialnej wobec Fidżi ${ }^{10}$. Tradycja i status wodza wraz z ideologią zbudowaną wokół tego urzędu służyły delegitymizacji roszczeń robotników kontraktowych z Indii i ich potomków. Specyficzny rys systemowi politycznemu nadawała Wielka Rada Wodzów (Bose Levu Vakutaraga), która mianując 1/3 ogólnej liczby członków izby wyższej parlamentu, celowo utrzymywała w nim niedoreprezentację społeczności hinduskiej ${ }^{11}$. Konsekwentnie rozwijana propaganda kolonialna i etniczna kolonizacja służyły skutecznemu przełamywaniu oporu wobec hegemonii ludności miejscowej ${ }^{12}$.

Rozłamy społeczne, stanowiące nieodłączną cechę sceny politycznej lat 70. i 80 . XX w., pogłębiały się zauważalnie w warunkach większościowego systemu wyborczego. Już sam mechanizm wytwarzający bipolarną scenę polityczną, tj. przy nadreprezentacji niektórych partii i niedostatecznej reprezentacji pozostałych, generalnie nie sprzyja przechodzeniu którejkolwiek z nich do centrum ${ }^{13}$. Podobnie w ramach silnie zatomizowanego parlamentu Fidżi, funkcjonującego jako organ wysoce niekoncyliacyjny, zantagonizowane strony pozostawały niechętne do podejmowania jakichkolwiek form współpracy.

9 Po wyborach w 1977 r. Sojusz skupił się na odbudowie zaufania tubylców, zwłaszcza wobec rozłamu wewnątrz partii i powstania Fidżyjskiej Partii Nacjonalistycznej (Fijian Nationalist Party, FNP); R. Norton, The Troubled Quest for National Political Leadership in Fiji, „The Round Table” 2015, nr 2, z. 104, s. 119.

10 S. Lawson, E. Hagan Lawson, Chiefly Leadership in Fiji: Past, Present, and Future, „SSGM Discussion Paper" 2015, nr 5, s. 2.

11 A. Rodd, Adapting postcolonial Island societes: Fiji and the Solomon Islands in the Pacific, „Island Studies Journal" 2016, nr 2, z. 11, s. 508.

12 S. Ramesh, Colonial and Post-Colonial Ethnocracy in Fiji, „Cosmopolitan Civil Societes Journal” 2016, nr 3, z. 8, s. 119-120.

13 G.B. Powell, Elections as Instruments of Democracy. Majoritarian and Proportional Visions, New Haven-London 2000, s. 198. 
Za koniec pierwszego etapu rozwoju systemu wyborczego Fidżi uznawany jest rok 1987 r. Zwycięstwo koalicji Partii Pracy (Labour) i NFP położyło kres sukcesom Sojuszu. W rezultacie dwukrotnego zamachu stanu zniesiono konstytucję z $1970 \mathrm{r}$. i dokonano zmiany ustroju na republikański. Po 1987 r., w efekcie masowego exodusu Hindusów do Australii, Nowej Zelandii czy Stanów Zjednoczonych, osadnicy z Indii stali się mniejszością $(43,7 \%)$ wobec większości etnicznych Fidżyjczyków $(50,07 \%)^{14}$. Nie pozostało to bez wpływu na sytuację ekonomiczną kraju. O ile bowiem w pierwszych latach niepodległości gospodarka rozwijała się w tempie niemal 5\% rocznie, o tyle wydarzenia z 1987 r., które odsłoniły kruchość demokracji i delegitymizację rządów w rezultacie nierównego podziału władzy, przełożyły się na gwałtowny spadek PKB (do 2,1\%) i poziomu zagranicznych inwestycji ${ }^{15}$.

\section{Między demokracją a etnokracją - w kierunku fidżyjskiego etnonacjonalizmu}

Status Fidżi jako republiki potwierdziła nowa, przyjęta na 7 lat, konstytucja z dnia 25 lipca 1990 r. ${ }^{16}$. Przejście do kolejnej fazy rozwoju systemu wyborczego oznaczało wzmocnienie rozwiązań zaczerpniętych z westminsterskiego systemu rządów i pozostawienie konstytucyjnej gwarancji szczególnej pozycji rdzennej ludności (art. 21) ${ }^{17}$. Zgodnie $z$ art. 41 tymczasowej ustawy zasadniczej wprowadzono głosowanie wzdłuż osi podziałów etnicznych. Wyborcy byli rejestrowani na jednej z czterech list wyborczych, wyodrębnionych na podstawie kryterium etnicznego. Obowiązywała odmienna podstawa prawna dla ustanowienia granic okręgów wyborczych głównych społeczności ${ }^{18}$. Przy tak zsegmentowanej rywalizacji wyborczej apel poszczególnych ugrupowań miał bardzo ograniczony zasięg i nie wykraczał poza jedną grupę etniczną. W 70-osobowej Izbie Reprezentantów 37 mandatów obsadzanych było w ramach miejsc „fidżyjskich”, a kolejne 27 - w tzw. miejscach „hinduskich” ${ }^{19}$. Aż 24 członków 34-sobowego Senatu pochodziło z mianowania przez Wielką Radę

14 A. Rodd, Adapting..., op. cit., s. 509.

15 S. Chand, The Political..., op. cit., s. 199-200.

16 Constitution of the Sovereign Democratic Republic of Fiji 1990 No. 22, www.paclii.org/f/promu/ promu_dec/cotsdrofd1990712.pdf (06.02.2019).

17 S. Ratuva, Fiji's Illusive Democracy: Paradoxes, Dilemmas and Hopes, „The Parlamentarian” 2012, z. 3, s. 188-189.

18 G. Hassall, Introduction: Systems of Representation in Asia-Pacific Constitutions - A Comparative Analysis, (w:) G. Hassall, C. Saunders (red.), The People's Representatives. Electoral Systems in the Asia-Pacific Region, Sydney 1997, s. 16.

19 Postulowano zagwarantowanie etnicznym Fidżyjczyków aż 58 z 90 mandatów i pozostawienie jedynie 20 miejsc do obsadzenia Hindusom; J. Fraenkel, The Triumph of the Non-Idealist Intellectuals? An Investigation of Fiji's 1999 Election Results, „Australian Journal of Politics and History” 2000 , nr 1, z. 46 , s. 87. 
Wodzów (art. 55 konstytucji). Przy rozdziale miejsc w Izbie Reprezentantów wyeksponowano ponadto oś podziału na linii miasto - wieś, zapewniając przewagę mieszkańcom wsi ${ }^{20}$.

Parlament zgodnie z art. 100 ust. 2 i 3 konstytucji zobligowany został do nadania szczególnej roli fidżyjskiemu prawu zwyczajowemu (Fijian customary law), będącemu częścią prawa Fidżi. Uznano, że kultura, zwyczaje i sposób życia rdzennej ludności powinny zyskać instytucjonalne wsparcie i przewagę nad pozostałymi, a ich interpretacją miała się zająć konstytucyjnie umocowana (art. 100 ust. 4) i specjalnie powołana w tym celu Komisja ds. Ziemi Rodzimej (Native Lands Commission). Warto podkreślić, że działalność tego gremium, jak i wielu innych miejscowych organów (w tym Wielkiej Rady Wodzów), wyłączono spod jurysdykcji rzecznika praw obywatelskich, a wydawane decyzje - pozostawiono poza zakresem właściwości sądów krajowych.

Miejscowej ludności przyznano parytet w dostępie do najwyższych stanowisk politycznych, w tym urzędu premiera. Szef rządu faktycznie decydował o obsadzie kluczowych urzędów w państwie oraz o wdrażaniu nieograniczonej liczby programów i polityk promujących szeroko pojętą ochronę interesów ludności rdzennie fidżyjskiej ${ }^{21}$. Efektywnym narzędziem służącym osłabieniu pozycji społeczności hinduskiej stała się możliwość odmowy przedłużenia im dzierżawy przez etnicznych Fidżyjczyków w sytuacji wygaśnięcia po co najmniej 30 latach umów najmu ziemi, zgodnie z ustawą o właścicielach i najemcach rolnych (Agricultural Landlord and Tenant Act, ALTA) z 1967 r. ${ }^{22}$.

Kierowanie się kryterium etnicznym na bazie założeń systemu westminsterskiego pozwoliło ukształtować na Fidżi ustrój oparty na sprzecznościach. Mieszanka ta, odzwierciedlona w przepisach konstytucji z 1970 i 1990 r., zawierała elementy zaczerpnięte zarówno z demokratycznej, jak i oligarchicznej formy rządów; umacniała unitaryzm; gwarantując autonomię jednej (melanezyjskiej) społeczności; bazowała na gospodarce rynkowej przy istniejących ograniczeniach odnośnie do ziemi i pracy; uznawała bliskie stosunki chrześcijaństwa z państwem, oficjalnie zachowując wolność religii; w końcu także podtrzymywała równość wszystkich, akceptując nadrzędność etnicznych Fidżyjczyków ${ }^{23}$. Owo dążenie jednej grupy etnicznej do sprawowania kontroli nad głównymi instrumentami władzy państwowej w ramach

20 D. Scarr, Current Developments in the Pacific. Fiji and the General Election of 1992, „Journal of Pacific History" 1993, nr 1, z. 28, s. 76-77.

21 Y. Ghai, J. Cottrell, A tale..., op. cit., s. 651-652.

22 Wzrost popularności teorii „wyzyskiwanego właściciela ziemskiego” skutkował propozycją wyłączenia najemców spod regulacji ALTA, de facto chroniącej najemców, i objęciem ich przepisami ustawy o administracji ziemią rodzimą (Native Land Trust Act, NLTA); O. Kurer, Land and Politics in Fiji: of Failed Land Reforms and Coups, „The Journal of Pacific History, nr 3, z. 36, s. 304-307.

Y. Ghai, J. Cottrell, A tale..., op. cit., s. 646. 
Konsekwencje ustrojowe reform systemu wyborczego Fidżi jako państwa...

wielonarodowej wspólnoty świadczy o ukształtowaniu się na Fidżi w latach 90. XX w. systemu zwanego etnokracją ${ }^{24}$.

\section{Westminster zanegowany: etniczność jako determinant reform wyborczych}

Trudności wynikające z funkcjonowania państwa zgodnie z logiką systemu westminsterskiego, w ramach którego jednopartyjny większościowy rząd (egzekutywa) dominował nad powiązaną $\mathrm{z}$ nim legislatywą, stanowiły bodziec do kolejnej zmiany konstytucji ${ }^{25}$. Jedność w łonie tworzonych gabinetów była fikcją wobec braku systemowych mechanizmów kontroli nad konstytucyjnymi organami państwowymi. Generowało to korupcję na najwyższych szczeblach władzy i niski poziom zaufania do rządzących ${ }^{26}$.

W 1994 r. doszło do utraty większości parlamentarnej przez partię Soqosoqo ni Vakavulewa ni Taukei (SVT), kreowaną na główną siłę polityczną ludności rdzennej. Polityczny ruch zjednoczenia etnicznych Fidżyjczyków, wspierany przez Wielką Radę Wodzów i establishment Fidżi, zdołał utrzymać polityczną dominację rządu nawet w obliczu tworzonych alternatywnych ugrupowań w nurcie regionalizmu partyjnego ${ }^{27}$. Premier Sitiveni Rabuki porozumiał się z liderem opozycyjnej NFP, na czele której stał Jai Ram Reddy, w celu wspólnego podjęcia się opracowania projektu nowej konstytucji. Poprzedzone to zostało kompleksowym przeglądem obowiązującej ustawy zasadniczej. W przedłożonym we wrześniu 1996 r. raporcie Komisji ds. Rewizji Konstytucji (Constitutional Review Commission, CRC) pt. „W kierunku wspólnej przyszłości” (Towards a United Future), znalazło się z szereg zaleceń dotyczących m.in. systemu wyborczego, kwestii narodowej jedności czy społeczno-ekonomicznego rozwoju kraju ${ }^{28}$.

Gremium to uznało, że skoro etniczność stanowi barierę dla efektywnej współpracy całego społeczeństwa, postanowienia przyszłej ustawy zasadniczej powinny

24 Zob. N.A. Butenschøn, Politics of Ethnocracies: Strategies and Dilemmas of Ethnic Domination, rozszerzona wersja artykułu prezentowanego na Ogólnokrajowej Konferencji Nauk Politycznych, Geilo, Norwegia, 11-12 stycznia 1993, www.statsvitsenkap.uio.no/ansatte/serie/notat/fulltekst/0193/Ethnocr-5.html (08.02.2019).

25 O ewolucji systemu politycznego Fidżi w kierunku modelu demokracji konsocjonalnej zob. M. Palmer, Democracy in Fiji: Westminster or something else?, (w:) H. Patapan, J. Wanna, P. Weller (red.), Westminster Legacies. Democracy and Responsible Government in Asia and the Pacific, Sydney 2005, s. 207-208.

26 A.L. Durutalo, Fiji: Party Politics in the Post Independence Period, (w:) R. Rich, L. Hambly, M.G. Morgan, Political Parties in the Pacific Islands, Canberra 2006, s. 174-175.

27 D. Scarr, Current..., op. cit., s. 89-90.

28 Pierwotna wersja raportu stanowiła rezultat prac tzw. komisji Reevesa (od nazwiska jej przewodniczącego Paula Reevesa, byłego gubernatora generalnego Nowej Zelandii); Y. Ghai, J. Cottrell, A tale..., op. cit., s. 653. 
zachęcać do powstawania partii i koalicji wieloetnicznych. Podkreślono, że poszanowanie zróżnicowania etnicznego Fidżi wymaga uwzględnienia interesów i aspiracji ludności rdzennej. Rekomendowano również zmianę obowiązującej ordynacji wyborczej na rzecz dość rzadkiej odmiany systemu większościowego, a mianowicie alternatywnego głosowania (Alternative Vote, $A V$ ), zwanego preferencyjnym albo też głosowaniem $\mathrm{z}$ bezpośrednią dogrywką ${ }^{29}$.

Celowość wprowadzenia nowej ordynacji wyborczej argumentowano potrzebą dostosowania się do wymogów społeczeństwa podzielonego etnicznie. Wskazywano, iż wiąże się to $\mathrm{z}$ przyznaniem reprezentacji i udziału w rządzeniu różnym grupom etnicznym, jak i koniecznością przeformułowania - postrzeganej jako fundament stosunków społecznych - zasady nadrzędności etnicznych Fidżyjczyków. Zwrócono uwagę, iż zalecane zmiany warunkowane są wielością ugrupowań wywodzących się $\mathrm{z}$ różnych społeczności oraz istnieniem heterogenicznych okręgów wyborczych ${ }^{30}$. Przyjęcie głosowania alternatywnego uzasadniano doświadczeniami innych państw wielokulturowych, w tym Republiki Południowej Afryki, Malezji, Szwajcarii, Belgii, a zwłaszcza Nowej Zelandii ${ }^{31}$

Uchwalenie trzeciej konstytucji w historii niepodległego Fidżi zapoczątkowało kolejny etap transformacji systemu wyborczego ${ }^{32}$. Ustawa zasadnicza (jak i późniejsza ustawa wyborcza z $1998 \mathrm{r}^{33}$ ), przyjęta została pod naciskiem społeczności międzynarodowej 25 lipca 1997 r. $^{34}$, zawierała wiele określanych mianem „postępowych” postanowień, w tym zgodnie z zaleceniami komisji, zastępujących większościową

29 Stosowany w Australii, częściowo w Irlandii, a w zmodyfikowanej postaci również w Papui-Nowej Gwinei i Nauru, system ten polega na wskazywaniu przez wyborców skali preferencji poszczególnych kandydatów. Przy braku większości bezwzględnej głosów mandat uzyskuje kandydat, który zdobył największe poparcie zgodnie z pierwszą preferencją; zob. Koncepcje systemów wyborczych, Opracowania tematyczne OT-578, Kancelaria Senatu: Biuro Analiz i Dokumentacji, Dział Analiz i Opracowań Tematycznych, marzec 2010, s. 14.

30 B.V. Lal, Fiji Constitution Review Commission recommendations for a new electoral system for Fiji, (w:) B.V. Lal, P. Larmour (red.), Electoral systems in divided societes: the Fiji Constitution Review, Canberra 2012, s. 44-50.

31 Wskazywano na wytyczne zawarte w raporcie pt. „W kierunku lepszej demokracji” (Towards a Better Democracy) z 1986 r., w którym rekomendowano wprowadzenie mieszanego systemu wyborczego $\mathrm{w}$ formie przedstawicielstwa proporcjonalnego (Mixed Member Proportional, MMP). Było to równoznaczne $\mathrm{z}$ odejściem od ugruntowanych tradycją rozwiązań zaczerpniętych $\mathrm{z}$ westminsterskiego modelu demokracji; zob. J. Bolger, New Zealand Politics in Flux, (w:) J. Vowles i in. (red.), Towards Consensus? The 1993 General Election in New Zealand and the Transition to Proportional Representation, Auckland 1995, s. 8-10.

32 Ustawa zasadnicza z 1997 r. wyróżniała się złożoną strukturą i rekordową liczbą 195 artykułów, zawartych aż w 16 rozdziałach; zob. P. Osóbka, Systemy konstytucyjne państw Oceanii, Warszawa 2012, s. 28.

33 Electoral Act 1998 No. 18, www.paclii.org/ff/legis/num_act/ea1998103/index.html (11.02.2019).

34 Fiji Island Constitution Amendment Act 1997 No. 13, www.wipo.int/edocs/lexdocs/laws/en/ff/ fj011en.pdf (12.02.2019). 
Konsekwencje ustrojowe reform systemu wyborczego Fidżi jako państwa...

formułę wyborczą głosowaniem alternatywnym przy utrzymaniu jednomandatowych okręgów wyborczych ${ }^{35}$.

Na mocy art. 50 konstytucji Izba Reprezentantów liczyła 71 miejsc, z których 46 przydzielano według kryterium rasy: 23 miejsca zarezerwowano dla rdzennej ludności, 19 - dla Hindusów, a 4 - dla pozostałych społeczności. Wbrew zaleceniom komisji utrzymano metodę nominacji członków do 34-osobowego Senatu (art. 64), zachowując wyraźny element etniczny w strukturze i sposobie funkcjonowania tej izby. Pewnym novum było ustanowienie 25 tzw. otwartych (wspólnych) list wyborczych (common roll seats), z których kandydować mogli wszyscy bez względu na przynależność etniczną (art. 51 ust 1b). Wielka Rada Wodzów zyskała umocowanie konstytucyjne, stając się z czasem gremium niezależnym od rządu ${ }^{36}$.

Ponowne wprowadzenie zmian w prawie wyborczym w założeniu służyć miało współpracy partii reprezentujących różne etniczne społeczności Fidżi, co po części osiągnięto. Faktycznie bowiem przepisy ustawy zasadniczej z 1997 r. stanowiły rezultat uzgodnienia stanowisk obu społeczności. Należy przy tym podkreślić, że mechanizm przesuwania głosów w tym systemie wyborczym generalnie sprzyja otrzymywaniu mandatów przez kandydatów bardziej umiarkowanych, którzy są w stanie uzyskać - chociaż nie w oparciu o tzw. pierwsze preferencje - akceptację większości wyborców. Jednak w praktyce głosujący dość rzadko rozdzielają własne preferencje pomiędzy kandydatów różnych opcji ${ }^{37}$, co tak jak w przypadku Fidżi wyraźnie wzmacniało proces stopniowej polaryzacji sceny partyjnej.

Wobec utrzymania ochrony prawa do ziemi i spraw etnicznych Fidżyjczyków przedwyborcze porozumienia okazały się być motywowane bardziej względami politycznymi i chłodną kalkulacją aniżeli wspólnie uzgodnionymi długofalowymi wizjami. Nowy system wyborczy osłabił zatem, lecz nie wyeliminował wciąż silnego oddziaływania czynnika rasowego przy braku zrównoważenia geograficznego ${ }^{38}$. Tym zaś elementem, który zadecydował ostatecznie o wyniku wyborów z 1999 r., nie była zmiana ordynacji wyborczej, ale wprowadzenie tzw. otwartych okręgów wyborczych.

\section{Nowa konstytucja: powrót do demokratycznej formy rządu?}

Nadzieje na to, iż elity polityczne wdrożą autentyczną politykę wieloetniczną, wygasły wraz z przeprowadzeniem dwóch zamachów stanu celem obalenia konsty-

35 W. Sokół, Główne tendencje w polityce reform wyborczych w wyborach parlamentarnych, „Annales Universitatis Mariae Curie-Skłodowska, Sectio K: Politologia” 2013, nr 2, t. 20, s. 127-128.

36 B.V. Lal, Heartbreak Islands: Reflections on Fiji in transition, „Asia Pacific Viewpoint” December 2003, nr 3, z. 44, s. 344.

37 B. Michalak, A. Sokala, Leksykon..., op. cit., 134-136.

38 Wiejskie okręgi wyborcze obejmowały średnio nawet dwa razy więcej zarejestrowanych wyborców niż okręgi miejskie. Wyboru kandydata w okręgach rdzennie fidżyjskich dokonywano jednak mniejszą liczbą głosów niż w okręgach hinduskich; zob. J. Fraenkel, op. cit., s. 88-90. 
tucji z 1997 r. Pierwszy, z maja 2000 r., położył kres funkcjonowaniu koalicyjnego gabinetu, na czele z Mahendrą Chaudhry, liderem Fidżyjskiej Partii Pracy (Fiji Labour Party, FLP), a zarazem pierwszym w historii tego kraju premierem pochodzenia hinduskiego ${ }^{39}$. Kontrolę nad państwem jako szef tymczasowego rządu przejął Frank (właśc. Josai Voreqe) Bainimarama, stojący na czele fidżyjskich sił zbrojnych (Republic of Fiji Military Forces, RFMF). Drugi zamach, z grudnia 2006 r., oficjalnie miał na celu zapewnienie ochrony ducha konstytucji przed "szkodliwą" polityką premiera Laisenia Quarase. Faktycznie jednak przejęcie kontroli nad państwem posłużyło F. Bainimaramie do wycofania dwóch projektów ustaw, na mocy których pozycja etnicznych Fidżyjczyków mogłaby ulec wzmocnieniu ${ }^{40}$.

Konsolidacja reżimu po 2006 r. odbywała się poprzez wdrażane reformy polityczne i gospodarcze, określane mianem Strategicznym ram dla zmian (Strategic Framework for Change $)^{41}$. Pogłębiający się kryzys wewnętrzny zaostrzyła decyzja Sądu Apelacyjnego z 9 kwietnia 2009 r., która uznała powołany w wyniku zamachu stanu z 2006 r. rząd za nielegalny. Przywrócony na najwyższy urząd w państwie na początku stycznia 2007 r. prezydent Josef Iloilo zaledwie dzień po wydaniu tej decyzji sądu uchylił konstytucję ${ }^{42}$.

W warunkach braku transparentności i odpowiedzialności w kierowaniu sprawami państwa, cenzury mediów oraz ograniczania wolności słowa przygotowywano nową ustawę zasadniczą, która oficjalnie miała skierować Fidżi na nowe, bardziej demokratyczne tory. Zapowiedź prezydenta J. Iloilo przeprowadzenia po ośmiu latach przerwy demokratycznych wyborów do parlamentu (jednak nie wcześniej niż we wrześniu 2014 r.) wskazywała na chęć zaprojektowania takiego systemu wyborczego, który uwzględniając zróżnicowanie etniczno-kulturowe społeczeństwa, zdołałby wzmocnić zdolność parlamentu do jak najwierniejszego odzwierciedlenia potrzeb i interesów obywateli ${ }^{43}$.

39 Zamiar obalenia rządu i uchylenia ustawy zasadniczej z 1997 r. udaremniono decyzją Sądu Najwyższego z dnia 15 listopada 2000 r. (potwierdzoną przez Sąd Apelacyjny 1 marca 2001 r.). Zamach stanu z 2000 r. uznano za niezgodny z konstytucją, którą utrzymano w mocy; R.R. Premdas, Seizure of power, indigenous rights and crafting democratic givernance in Fiji, „Nationalism and Ethnic Politics" Winter 2002, nr 4, z. 8, s. 32-33.

40 R. Robertson, Cooking the Goose: Fijis Coup Culture Contextualised, „The Round Table” December 2012, nr 6, z. 101, s. 518.

41 S. Tarte, The Politics of Transition in Fiji: Is it Charting a Democratic Course?, „Australian Journal of Politics and History" 2018, nr 2, z. 64, s. 281.

$42 \mathrm{Z}$ dniem 10 kwietnia 2009 r. zaczęły obowiązywać przepisy właściwe dla stanu wyjątkowego ( $P \mathcal{u}$ blic Emergency Regulations, PER). Posługując się retoryką „wspólnego dobra” i budowania dobrobytu kraju, rząd uzasadniał stosowane przez siebie praktyki znacznie ograniczające prawa i wolności jednostki; P. Hodge, A Progressive Authoritarianism? The case of post-2006 Fiji, „Third World Quarterly", nr 6, z. 33, s. 1154-1156.

43 Źródła porażki demokratycznych mechanizmów w tym państwie zwykło się upatrywać głównie w ordynacji wyborczej. Można jednak wskazać argumenty przeciwne, wskazujące, że manipula- 
W celu opracowania projektu konstytucji powołano 5-osobową komisję konstytucyjną (Constitution Commission), której przewodniczył ekspert z dziedziny prawa konstytucyjnego Yash $\mathrm{Gai}^{44}$. Projekt, stanowiący efekt prac tego gremium oraz szeroko zakrojonych konsultacji społecznych (w sumie ponad 7 tysięcy zgłoszonych wniosków), niespodziewanie nie wszedł w życie. Obecnie obowiązująca konstytucja to dokument rządowy, opracowany jako „Plan dla lepszego Fidżi” ('BluePrint for a better Fiji'), tylko w niewielkim stopniu nawiązujący do ustaleń komisji. Kanwę dla przyjętych regulacji prawnych stanowiła Karta Ludu (People's Charter lub People's Charter for Change, Peace and Progress), opracowywana od 2007 r. pod kierunkiem F. Bainimaramy ${ }^{45}$.

Na mocy ustawy zasadniczej z dnia 6 września 2013 r. ${ }^{46}$ wprowadzono szereg istotnych zmian, głównie w przedmiocie prawa wyborczego. Pożądane skutki dotychczasowych regulacji w tym obszarze prawa, z punktu widzenia realizacji funkcji integracyjnej wyborów i pokojowego rozwiązywania konfliktów o władzę w podzielonym etnicznie społeczeństwie fidżyjskim ${ }^{47}$, uznano za niewystarczające. Obowiązujący od 1997 r. system alternatywnego głosowania zastąpiono systemem proporcjonalnym (Proportional Representation, $P R)^{48}$. Uznano, że element proporcjonalności, rozumiany jako zagwarantowanie każdej partii politycznej takiego udziału we władzy, jaki bezpośrednio wynika $z$ wielkości udzielonego jej poparcia, bardziej niż preferencyjności, wzmocni wieloetniczną współpracę polityczną, a rolę opozycji ograniczy do zachowań zgodnych z normami demokratycznymi ${ }^{49}$.

cje systemem, w celu uzyskania władzy, mogą być dokonywane przez dowolną partię polityczną bądź społeczność etniczną; zob. S. Kumar, B.C. Prasad, Preferential voting and Political Engineering: The case of Fiji's 1999 and 2001 general elections, „Commonwealth \& Comparative Politics” November 2004, nr 3, z. 42, s. 315; por. D.G. Arms, The case for reform of the electoral system in Fiji, (w:) J. Fraenkel, S. Firth (red.), From Election to Coup in Fiji: The 2006 campaign and its aftermath, Canberra 2007, s. 385 i n.; B. Reilly, Evaluating the effect of the electoral system in postcoup Fiji, „Pacific Economic Bulletin” May 2001, nr 1, z. 16, s. 145 i n.

44 S. Lawson, Indigenous Nationalism, „Ethnic Democracy”, and the prospects for a Liberal Constitutional Order in Fiji, „Nationalism and Ethnic Politics” 2012, nr 3, z. 18, s. 310.

45 Dokument ten stanowić miał skuteczne narzędzie rządu do realizacji programu kształtowania tożsamości społecznej; P. Hodge, A Progressive..., op. cit., s. 1156-1158.

46 Constitution of the Republic of Fiji, www.paclii.org/fj/Fiji-Constitution-English-2013.pdf (26.10.2018).

47 A. Surówka, Kompendium prawa konstytucyjnego dla studentów administracji. Zasady ustroju, prawo wyborcze i status jednostki, Kraków 2013, s. 29.

48 Głównym argumentem za przyjęciem metody proporcjonalnej był bardziej sprawiedliwy podział mandatów, zapewniający wyższy poziom reprezentatywności, a zatem również legitymacji systemowi politycznemu; zob. B. Michalak, A. Sokala, Leksykon..., op. cit., s. 109-111.

49 Proporcjonalna ordynacja wyborcza sprzyja silniejszemu postrzeganiu społeczeństwa w kategoriach jednego narodu, do którego odwołują się wieloetniczne w swojej strukturze partie polityczne, a także większej dystrybucji mandatów prowadzącej do aktywniejszej partycypacji politycznej kobiet; S. Ratuva, Legitimizing Regime Change: Fiji's New Constitution and the 2014 Election, „The Parlamentarian” 2013, z. 3, s. 184-185. 
Doniosłą zmianą instytucjonalną było zniesienie Senatu, a w jego miejsce ustanowienie 50-osobowego organu ustawodawczego o strukturze jednoizbowej (unicameral). Ustanowiono jeden okręg wyborczy, w którym można zdobyć 50 mandatów (art. 54 konstytucji), przydzielanych metodą d'Hondta przy zastosowaniu 5\% klauzuli zaporowej (art. 53 ust. 3$)^{50}$. Obniżono cenzus wieku dla czynnego prawa wyborczego z 21 do 18 lat (art. 55) ${ }^{51}$. Odstąpiono również od założenia, przyjmowanego we wcześniejszych ustawach zasadniczych, że odgórnie ustalona liczba mandatów dla poszczególnych wspólnot zapewni im równe przedstawicielstwo w parlamencie. $\mathrm{Na}$ mocy art. 53 ust. 1 konstytucji oraz art. 23 ust. 4 ustawy wyborczej z 2014 r. potwierdzono formalną i materialną równość głosu obywateli poprzez zniesienie etnicznych list wyborców i ich odrębnych reprezentacji w organie ustawodawczym ${ }^{52}$. Po raz pierwszy w historii Fidżi zagwarantowano równouprawnienie wszystkim grupom etnicznym ${ }^{53}$.

W przepisach nowej konstytucji nie uczyniono wzmianki na temat Wielkiej Rady Wodzów, której likwidację F. Bainimarama ogłosił już w marcu 2012 r. ${ }^{54}$. Uzasadniając to posunięcie, stwierdził, że Rada stanowi anachronizm epoki kolonialnej, nie będący w stanie dłużej pełnić pozytywnej roli w państwie. W ocenie wielu organ ten, tytułujący się strażniczką tradycji fidżyjskiej, a przez to niejednokrotnie stawiający siebie ponad obowiązującym prawem, przeobrażał się de facto w coraz bardziej upolitycznione gremium, skutecznie zapewniające rdzennym Fidżyjczykom przywódczą rolę w państwie ${ }^{55}$.

Swoistym sprawdzianem dla wprowadzonych unormowań prawnych były wybory parlamentarne z 17 września $2014 \mathrm{r}$. Walka wyborcza oznaczała w istocie rywalizację dwóch przeciwstawnych opcji opartych na kryterium ideologicznym,

50 Te trzy nowe rozwiązania preferują duże ugrupowania kosztem partii mniejszych, co w rezultacie wzmacnia efektywność funkcjonowania parlamentu; zob. A. Stelmach, Manipulacje prawem wyborczym i ich wpływ na legitymizację władzy w Polsce, (w:) S. Patyra, M. Sadowski, K. Urbaniak (red.), Konstytucja w państwie demokratycznym, Poznań 2017, s. 200-206.

51 Co już podczas wyborów parlamentarnych w 2014 r., gdy wielu wyborców młodszego pokolenia oddało swój głos, przyczyniło się do wyborczego triumfu F. Bainimaramy; S. Ratuva, Legitimizing..., op. cit., s. 185.

52 Electoral Act 2014 No. 11, www.feo.org.fj/wp-content/uploads/2017/03/Electoral-Act-2014.pdf (14.03.2019).

53 B.V. Lal, In Frank Bainimarama's Shadow: Fiji, Elections and the Future, „The Journal of Pacific History" 2014, nr 4, z. 49, s. 459-461.

54 W kwietniu 2016 r. wpłynęła petycja w sprawie przywrócenia tego organu, odrzucona przez rząd F. Bainimaramy stosunkiem głosów 29 do 16; zob. Fiji's Great Coucil of Chiefs will not be reinstated, www.country.eiu.com/(F(FwEeus9YORcMy8UH00Ehf_UJKxG6oHNILng8Zan5VPxjYfZVwTyu1mHAnfBMsqZ9pGp6bPOzyvcb0UGRXpRqXHqwHT5Ygxts2QJTLK4GiIk1))/article. aspx ?articleid $=884168072 \&$ Country $=$ Fiji\&topic $=$ Politics\&subtopic $=$ Forecast\&subsubtopic $=$ Political+stability (28.02.2019). 
Konsekwencje ustrojowe reform systemu wyborczego Fidżi jako państwa...

a nie, jak do tej pory, rasowym ${ }^{56}$. Koalicyjny blok SODELPA (Social Democratic Liberal Party), odwołujący się do ochrony tradycji oraz utrzymania systemu wodzostwa rdzennych mieszkańców, rywalizował z reformatorską orientacją partii Najpierw Fidżi (FijiFirst) ${ }^{57}$. Podejście nacjonalistyczne przyciągnęło duży odsetek głosów iTau$k e i$, lecz uznane zostało za zagrożenie dla bezpieczeństwa pozostałych społeczności etnicznych. Ugrupowanie Najpierw Fidżi stało się niekwestionowanym zwycięzcą tych wyborów, otrzymując 59,2\% głosów (tj. 32 mandaty) ${ }^{58}$. Opozycyjny blok SODELPA zdobył jedynie 28,2 \% (tj. 15 mandatów) $)^{59}$.

Sukces ugrupowania J.V. Bainimaramy oceniać należy w aspekcie wdrażanej przez niego wizji państwa egalitarnego. Nowe, progresywne podejście, wskazujące na konieczność transformacji państwa poprzez reformy ukierunkowane na wspieranie różnych społeczności etnicznych, świadczyło o doniosłej zmianie wizerunkowej dotąd bardzo konserwatywnego wojska. Za pomocą różnych zabiegów, mających na celu uzyskanie zgody na rządzenie ${ }^{60}$, ów „nowy-stary” przywódca zdołał uzasadnić zarówno zamachy stanu, jak i metody autorytarne stosowane po 2009 r., tj. w okresie przedłużonego jego własną decyzją stanu wyjątkowego.

Ze względu na ogromne znaczenie przypisywane wyborom z 2014 r. zasadne staje się pytanie, czy rzeczywiście stanowiły one zwrot ku procedurom demokratycznym, a tym samym pierwszy etap transformacji państwa. Zauważyć można, iż w trakcie tej elekcji dominowały głosy krytyki, a nawet pogardy wobec opozycji. Konsekwentnie podtrzymywana retoryka konfliktu ukazywała rząd w roli gwaranta demokracji, stronę przeciwną zaś jako nieudolną czy wręcz szkodliwą dla państwa. Niepokojem mógł napawać rządowy sprzeciw wobec wdrożenia zaleceń międzynarodowej grupy obserwatorów i komisji wyborczej z 2014 r., odnoszących się do wielu istotnych kwestii związanych z mediami, organizacjami pozarządowymi, partiami politycznymi oraz kandydatami ${ }^{61}$.

W swojej narracji partia rządząca podważyła podstawowe założenia establishmentu Fidżi, utrzymując ster rządów w rękach bardzo wąskiej elity politycznej. Niewątpliwie władza pozostaje w gestii zaledwie dwóch osób: F. Bainimaramy i jego

56 J. Fraenkel, An Analysis of Provincial, Urban and Ethnic Loyalties in Fijis Election, „The Journal of Pacific History" 2015, nr 1, z. 50, s. 49-50.

57 SODELPA to następczyni partii Soqosoqo Duavata ni Lewenivanua (SDL), zwyciężczyni wyborów parlamentarnych z $2001 \mathrm{r}$. Jej sztandarowym hasłem była ochrona interesów rdzennej ludności; P. Carnegie, S. Tarte, op. cit., s. 282.

58 S. Ratuva, Protectionism versus Reformism: The Battle for Taukei Ascendancy in Fijis 2014 General Election, „Round Table” 2015, nr 2, z. 104, s. 143-146.

59 Jedyną partią polityczną, która zdobyła pozostałe 3 mandaty, była Partia Federacji Narodowej; J. Fraenkel, The Remorselles Power of Incumbency in Fijis September 2014 Election, „The Round Table" 2015, nr 2, z. 104, s. 152.

$60 \quad$ Ibidem, s. 153.

61 P. Carnegie, S. Tarte, op. cit., s. 284-285. 
zastępcy Aiyaza Sayed-Khaiyumy ${ }^{62}$. Ekipa rządząca ze swego rodzaju testu poparcia społecznego, w wyniku którego mogła zostać „ukarana” przez elektorat, wyszła zwycięsko. Po 2014 r. znalazła się w samym centrum nowego układu politycznego, zmuszającego ją do współpracy z innymi demokratycznie wybranymi organami, w tym z parlamentem. Tymczasem bliskie związki premiera z wojskiem wskazują, że organ ustawodawczy i inne instytucje przedstawicielskie nie są traktowane jako źródło legitymacji do rządzenia, lecz użyteczne narzędzie służące zachowaniu dominującej pozycji w państwie przez F. Bainimaramę. Zatem gdy wymagana była zmiana środków i narzędzi służących do wypracowania nowych zasad, postawiono na kontynuację już obranej drogi zgodnie z hasłem wyborczym „więcej tego samego".

Wynik wyborów z 14 listopada 2018 r. miał potwierdzić względną stabilność polityczną, wiarygodność zapowiedzi rozwoju ekonomicznego państwa i podniesienia standardu życia jego mieszkańców, aby stworzyć zapowiadane „nowe Fidżi”63. Zgodnie z przewidywaniami obywatele tego państwa po raz kolejny powierzyli F. Bainimaramie mandat do rządzenia ${ }^{64}$, co pozwoliło zachować istniejące status quo. W warunkach owej pozornej stabilności, jako że opartej na dobrej woli i partykularnych interesach wciąż tej samej elity politycznej, wszelkie próby wdrożenia odmiennego stylu polityki i wizji rozwoju państwa uznać należy za bezcelowe w perspektywie co najmniej kilku kolejnych lat.

\section{Wnioski końcowe}

Można przyjąć, że cały okres państwowości Fidżi to cykl następujących po sobie nieregularnych demokratycznych wyborów i antydemokratycznych zamachów stanu $^{65}$. Przyczyn takiej powtarzającej się sekwencji zdarzeń można upatrywać w niewystarczającej woli politycznej decydentów, jak i braku zdolności istniejących instytucji politycznych do radzenia sobie z głębokimi podziałami etnicznymi w państwie. Słabość cywilnych rządów implikowała wzmocnienie pozycji armii, która - przy

62 Pod kontrolą A. Sayed-Khaiyumy znalazło się szereg resortów, w tym finansów, komunikacji, przedsiębiorstw publicznych, ponadto prokuratura generalna; B.V. Lal, In Frank..., op. cit., s. 458459.

63 Cyt. za: ibidem, s. 464, 468.

64 Partia Najpierw Fidżi zdobyła 50,02\% głosów, tj. 27 mandatów, co pozwoliło jej po raz kolejny na samodzielne powołanie rządu; Frank Bainimarama sworn in as Fiji PM, 20 November 2018, www.radionz.co.nz/international/pacific-news/376364/frank-bainimarama-sworn-in-as-fiji-pm (01.03.2019).

65 Ukuto nawet wobec Fidżi termin „kultury zamachów stanu” (coup culture); za: J. Fraenkel, The Remorselles..., op. cit., s. 152. 
braku wyraźnych granic między władzą a społeczeństwem - tradycyjnie postrzegana była jako reprezentacja interesów autochtonów ${ }^{66}$.

Już wynik wyborczy z 1999 r. powinien skłaniać do refleksji, że polityka międzyetniczna powinna nagradzać każdy przejaw zachowań koncyliacyjnych, nawet jeśli te zasadniczo dotąd nie istniały ${ }^{67}$. Przykład "koalicji przeciwieństw” (coalition of opposites) dowodził, że wprowadzony w 1997 r. system głosowania alternatywnego nie był na tyle efektywny, aby w pełni złagodzić istniejące konflikty społeczne. Rezultaty wyborów z 2001 i 2006 r. potwierdziły, że ugrupowania polityczne mogą skutecznie mobilizować rdzenną większość, ignorując aspiracje hinduskiej mniejszości niejako wbrew założeniom ordynacji wyborczej. Obie elekcje ujawniły, że zamiar budowania wieloetnicznej demokracji reprezentacyjnej w oparciu o konstytucję z 1997 r. nie powiódł się. Przyjęcie nowej ordynacji wyborczej umożliwiło jednak zgromadzenie głównych antagonistów w ramach podzielonego społeczeństwa, zachęcając ich do szukania porozumienia ${ }^{68}$.

Kolejne zamachy stanu utorowały drogę przywódcom, którzy okresy relatywnej demokratyzacji, zwłaszcza w tzw. okresie przejściowym po 2006 r., wykorzystali do działań na rzecz swojego środowiska, a nie ogółu obywateli. W tym kontekście szczególnego znaczenia nabiera wprowadzenie w 2014 r. głosowania według własnych preferencji, a nie wzdłuż osi podziałów etnicznych. Miało to doniosłe konsekwencje dla ustroju społeczno-politycznego Fidżi, gdyż zahamowało polaryzację społeczeństwa (wywołaną celowym upolitycznianiem podziałów etnicznych) i radykalizację rywalizacji międzyetnicznej. Zmiany w strategiach partii politycznych wraz z poszerzaniem elektoratu o wyborców spoza ich własnej grupy etnicznej skutkowały obniżeniem poziomu napięcia w państwie.

Jednak stosowane obecnie metody rządzenia, przy wydatnym udziale siły wojskowej, świadczą o tym, że mamy do czynienia z iluzją demokratyzacji na Fidżi. Kryje się pod nią mieszanka demokratycznych instytucji i autorytarnych praktyk piastunów władzy, czego swoistą egzemplifikacją był przebieg procesu legislacyjnego w związku z nową konstytucją ${ }^{69}$. Ewolucja ustroju w kierunku demokracji fasadowej stanowi poważne wyzwanie, gdyż nie jest ona w stanie rozwiązać kluczowych pro-

66 Silne zaangażowanie w międzynarodowe operacje pokojowe paradoksalnie pozwoliło etnicznie monokulturowym siłom zbrojnym rozwinąć zdolności niezbędne do przeprowadzenia kolejnych zamachów stanu; J. Eska-Mikołajewska, Stability and Instability in Oceania: The Case of Papua New Guinea, the Solomon Islands and Fiji, (w:) D. Zdziech (red.), Oceania. An Important Part of the Pacific, Kraków 2018, s. 136-137.

67 D.L. Horowitz, Where have all the parties gone? Fraenkel and Grofman on the alternative vote yet again, Public Choice 2007, z. 133, s. 20.

68 S. Ramesh, Preferential voting and Indo-Fijian minority strategy, „Journal of Peace Conflict \& Development" 10 March 2007, www.peacestudiesjournal.org.uk (12.02.2019).

69 Nadmierna swoboda dokonywania zmian w obszarze prawa wyborczego pozwala wysunąć wniosek o koniunkturalizmie politycznym wśród fidżyjskich elit politycznych. Odzwierciedla się to ukierunkowywaniem reform na osiąganie dobrego rezultatu w wyborach przy jednoczesnym 
blemów tego mikrokraju. Budowanie prawdziwej demokracji wymaga rzeczywistej zmiany w podejściu do instytucji państwa, w założeniu służebnych wobec wszystkich równo traktowanych obywateli, a także przemian w sferze intelektualnej, emocjonalnej i społecznej. Do tak rozumianej transformacji systemowej, pomimo licznych zmian instytucjonalnych, wciąż nie doszło. Reformy przeprowadzane z wykorzystaniem tej samej siły politycznej, aparatu urzędniczego, ośrodków opiniotwórczych czy ekonomicznych oznaczają de facto konsolidację trwających rządów.

Dlatego też cechy, jakie Fidżi wykazywało w momencie przyjmowania nowej konstytucji w 2013 r., gdy sklasyfikowane zostało jako państwo bardzo wysoko zagrożone dysfunkcjonalnością ${ }^{70}$ w dalszym ciągu implikują słabość politycznych instytucji oraz trudności w rozwoju gospodarczym ${ }^{71}$. Autorytarny kurs władzy, działający początkowo w warunkach stanu wyjątkowego, okazuje się skuteczny także w obecnych realiach politycznych. Stabilizacji nie zagwarantuje jednak ani podważanie wyniku kolejnych wyborów do parlamentu, ani też hipotetyczne przejęcie władzy przez siły opozycji. Demokratyczne przemiany ustrojowe powinny polegać na budowaniu solidnych ram instytucjonalno-prawnych oraz wzmacnianiu przekonania o silnym społecznym mandacie dla władzy. W warunkach społeczeństwa podzielonego etnicznie to właśnie w najwyższym stopniu oddziałuje na reprezentatywność i faktyczną zdolność do rządzenia w państwie.

\section{BIBLIOGRAFIA}

Arms D.G., The case for reform of the electoral system in Fiji, (w:) J. Fraenkel, S. Firth (red.), From Election to Coup in Fiji: The 2006 campaign and its aftermath, Canberra 2007.

Bolger J., New Zealand Politics in Flux, (w:) J. Vowles i in. (red.), Towards Consensus? The 1993 General Election in New Zealand and the Transition to Proportional Representation, Auckland 1995.

Butenschøn N.A., Politics of Ethnocracies: Strategies and Dilemmas of Ethnic Domination, rozszerzona wersja artykułu prezentowanego na Ogólnokrajowej Konferencji Nauk Politycznych, Geilo, Norwegia, 11-12 stycznia 1993, www.statsvitsenkap.uio.no/ansatte/serie/notat/fulltekst/0193/ Ethnocr-5.html.

Chand S., The Political Economy of Fiji: Past, Present and Prospects, „The Round Table” 2015, nr 2, z. 104.

CIA World Factbook, www.cia.gov/library/publications/the-world-factbook/geos/fj.html.

Czaplicki K.W., O potrzebie stabilności prawa wyborczego. Wybrane problemy, Toruń 2009.

Duncan R., Chand S., The Economics of the 'Arc of Instability', "Asia-Pacific Economic Literature" maj 2002, nr 1, z. 16.

osłabianiu ich politycznych oponentów; zob. K.W. Czaplicki, O potrzebie stabilności prawa wyborczego. Wybrane problemy, Toruń 2009, s. 10-13.

70 Fragile States Index 2013, www.fundforpeace.org/fsi/data (02.03.2019).

71 Zob. R. Duncan, S. Chand, The Economics of the 'Arc of Instability"'Asia-Pacific Economic Literature" May 2002, nr 1, z. 16, s. 2-6. 
Durutalo A.L., Fiji: Party Politics in the Post Independence Period, (w:) R. Rich, L. Hambly, M.G. Morgan, Political Parties in the Pacific Islands, Canberra 2006.

Eska-Mikołajewska J., Stability and Instability in Oceania: The Case of Papua New Guinea, the Solomon Islands and Fiji, (w:) D. Zdziech (red.), Oceania. An Important Part of the Pacific, Kraków 2018.

Fraenkel J., The Remorselles Power of Incumbency in Fijis September 2014 Election, „The Round Table” 2015, nr 2, z. 104.

Fraenkel J., An Analysis of Provincial, Urban and Ethnic Loyalties in Fiji's Election, „The Journal of Pacific History" 2015, nr 1, z. 50.

Fraenkel J., The Triumph of the Non-Idealist Intellectuals? An Investigation of Fijis 1999 Election Results, „Australian Journal of Politics and History” 2000, nr 1, z. 46.

Fragile States Index 2013, www.fundforpeace.org/fsi/data.

Frank Bainimarama sworn in as Fiji PM, 20 November 2018, www.radionz.co.nz/international/pacificnews/376364/frank-bainimarama-sworn-in-as-fiji-pm.

Ghai Y., Cottrell J., A tale of three constitutions: Ethnicity and politics in Fiji, „International Journal of Constitutional Law" 2007, nr 4, z. 5.

Hassall G., Introduction: Systems of Representation in Asia-Pacific Constitutions - A Comparative Analysis, (w:) G. Hassall, C. Saunders (red.), The People’s Representatives. Electoral Systems in the Asia-Pacific Region, Sydney 1997.

Hodge P., A Progressive Authoritarianism? The case of post-2006 Fiji, „Third World Quarterly”, nr 6, z. 33.

Horowitz D.L., Where have all the parties gone? Fraenkel and Grofman on the alternative vote - yet again, Public Choice 2007.

Koncepcje systemów wyborczych, Opracowania tematyczne OT-578, Kancelaria Senatu: Biuro Analiz i Dokumentacji, Dział Analiz i Opracowań Tematycznych, marzec 2010.

Kumar S., Prasad B.C., Preferential voting and Political Engineering: The case of Fijis 1999 and 2001 general elections, „Commonwealth \& Comparative Politics” November 2004, nr 3, z. 42.

Kurer O., Land and Politics in Fiji: of Failed Land Reforms and Coups, „The Journal of Pacific History” 2013, nr 3, z. 36.

Lal B.V., In Frank Bainimarama's Shadow: Fiji, Elections and the Future, „The Journal of Pacific History” 2014, nr 4, z. 49.

Lal B.V., Fiji Constitution Review Commission recommendations for a new electoral system for Fiji, (w:) B.V. Lal, P. Larmour (red.), Electoral systems in divided societes: the Fiji Constitution Review, Canberra 2012.

Lal B.V., Heartbreak Islands: Reflections on Fiji in transition, „Asia Pacific Viewpoint” December 2003, nr 3, z. 44 .

Lawson S., E. Hagan Lawson, Chiefly Leadership in Fiji: Past, Present, and Future, „SSGM Discussion Paper" 2015, nr 5.

Lawson S., Indigenous Nationalism, „Ethnic Democracy”, and the prospects for a Liberal Constitutional Order in Fiji, „Nationalism and Ethnic Politics, 2012, nr 3, z. 18.

Lijphart A., Democracies. Patterns of Majoritarian and Consensus Government in Twenty-One Countries, New Haven and London 1984. 
Michalak B., Sokala A., Leksykon prawa wyborczego i systemów wyborczych, Warszawa 2010.

Norton R., The Troubled Quest for National Political Leadership in Fiji, „The Round Table” 2015, nr 2, z. 104 .

Osóbka P., Systemy konstytucyjne państw Oceanii, Warszawa 2012.

Palmer M., Democracy in Fiji: Westminster or something else?, (w:) H. Patapan, J. Wanna, P. Weller (red.), Westminster Legacies. Democracy and Responsible Government in Asia and the Pacific, Sydney 2005.

Powell G.B., Elections as Instruments of Democracy. Majoritarian and Proportional Visions, New Haven-London 2000.

Premdas R.R., Seizure of power, indigenous rights and crafting democratic governance in Fiji, „Nationalism and Ethnic Politics" Winter 2002, nr 4, z. 8.

Ramesh S., Colonial and Post-Colonial Ethnocracy in Fiji, „Cosmopolitan Civil Societes Journal” 2016, nr 3, z. 8.

Ramesh S., Preferential voting and Indo-Fijian minority strategy, „Journal of Peace Conflict \& Development" 10 March 2007, www.peacestudiesjournal.org.uk.

Ratuva S., Protectionism versus Reformism: The Battle for Taukei Ascendancy in Fijis 2014 General Election, „Round Table” 2015, nr 2, z. 104.

Ratuva S. Legitimizing Regime Change: Fiji's New Constitution and the 2014 Election, „The Parlamentarian" 2013, z. 3.

Ratuva S., Fiji's Illusive Democracy: Paradoxes, Dilemmas and Hopes, „The Parlamentarian” 2012, z. 3.

Reilly B., Evaluating the effect of the electoral system in post-coup Fiji, „Pacific Economic Bulletin” May 2001, nr 1, z. 16.

Robertson R., Cooking the Goose: Fiji’s Coup Culture Contextualised, „The Round Table” December 2012, nr 6, z. 101.

Rodd A. Adapting postcolonial Island societes: Fiji and the Solomon Islands in the Pacific, „Island Studies Journal" 2016, nr 2, z. 11.

Scarr D., Current Developments in the Pacific. Fiji and the General Election of 1992, „Journal of Pacific History" 1993, nr 1, z. 28.

Sokół W., Główne tendencje w polityce reform wyborczych w wyborach parlamentarnych, „Annales Universitatis Mariae Curie-Skłodowska, Sectio K: Politologia”, 2013, nr 2, t. 20.

Stelmach A., Manipulacje prawem wyborczym i ich wpływ na legitymizację władzy w Polsce, (w:) S. Patyra, M. Sadowski, K. Urbaniak (red.), Konstytucja w państwie demokratycznym, Poznań 2017.

Surówka A., Kompendium prawa konstytucyjnego dla studentów administracji. Zasady ustroju, prawo wyborcze i status jednostki, Kraków 2013.

Świeca J., Współczesne systemy demokratyczne cz. I. Wybrane zagadnienia z problematyki wyborczej oraz makroanalizy systemowej w ujęciu porównawczym, Kielce 2003.

Tarte S., The Politics of Transition in Fiji: Is it Charting a Democratic Course?, „Australian Journal of Politics and History" 2018, nr 2, z. 64.

Żukowski A., Systemy wyborcze, Olsztyn 1999. 